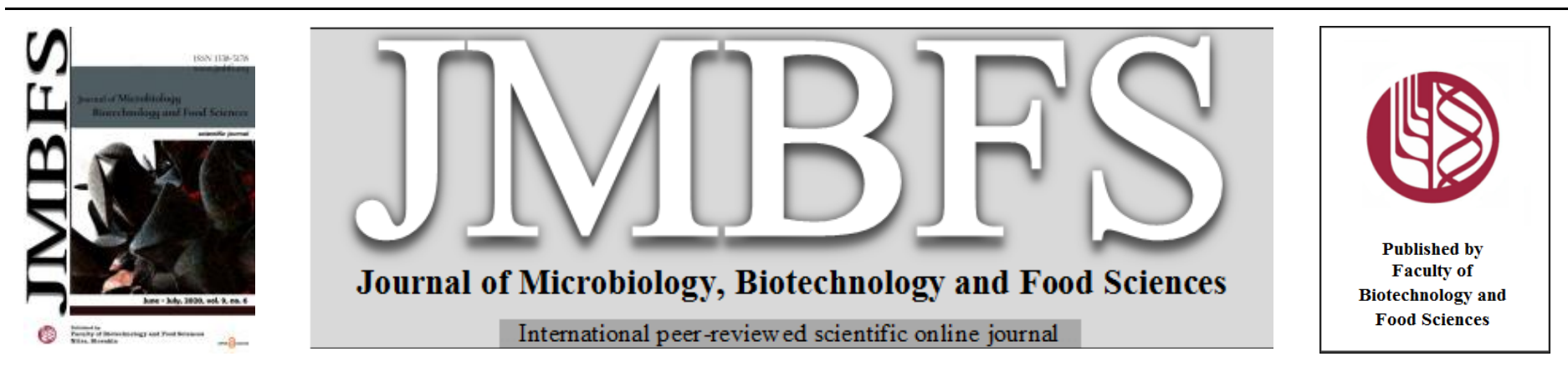

\title{
QUALITY ASSESSMENT OF COOKIES MADE FROM COMPOSITE FLOUR OF WHEAT, SORREL SEED PROTEIN ISOLATE AND YELLOW CASSAVA FLOURS
}

\section{Toibudeen Adesegun Sanni* ${ }^{1}$, Omolola Hubeidah Gbolagade ${ }^{1}$ Eunice Moriyike Ogunbusola ${ }^{1}$, Kudirat Titilayo Araoye ${ }^{2}$}

Address(es): Dr Toibudeen Adesegun Sanni

1 Federal University Oye, Faculty of Agriculture, Department of Food Science and Technology, P.M.B 573, Oye, Ekiti Stete, Nigeria.

2 Federal University Oye, Faculty of Agriculture, Department of Hospitality and Tourism Management, P.M.B 573, Oye, Ekiti Stete, Nigeria.

*Corresponding author: toibudeen.sanni@ fuoye.edu..ng

doi: 10.15414/jmbfs.2020.9.6.1073-1079

\section{ARTICLE INFO}

Received 11. 6. 2019

Revised 10. 1. 2020

Accepted 20. 1. 2020

Published 1. 6. 2020

Regular article

open $\odot$ access

\begin{abstract}
An investigation to examine the impart of replacement of wheat flour with sorrel seed protein isolate and High Quality Cassava Flour (HQCF) made from yellow flesh cassava (TMS/BA/1368) on the attributes of cookies made from their blends was carried out. Wheat flour was blended with Sorrel seed protein isolate and cassava flour at the ratios of 100:0:0 $\left(\mathrm{W}_{100: 0: 0}\right)$, 85:5:15 ( $\left.\mathrm{W}_{\text {85:5:10 }}\right)$, 70:10:20 $\left(\mathrm{W}_{70: 10: 20}\right)$ and 55:15:30 $\left(\mathrm{W}_{55: 15: 30}\right)$ respectively. The proximate, functional, mineral, pasting and sensory attributes of composite flours were evaluated using standard methods.

The results obtained showed that crude protein content, crude fat content, ash and crude fibre increased significantly $(\mathrm{p}<0.05)$, as the level of replacement increased, while the moisture and carbohydrate contents were significantly decreased as the level of inclusion increased. The level of carotenoids in the cookies sample also significantly increased along the level of inclusion. Functional characteristics such as water and oil absorption, foaming and swelling capacities increased significantly $(\mathrm{p}<0.05)$ as the wheat flour reduced, while packed and loose bulk densities and $\mathrm{pH}$, decreased accordingly. The mineral constituent of the cookies were significantly $(\mathrm{p}<0.05)$ elevated as the wheat flour substitution increased. The pasting characteristics of the blends showed an increase in peak viscosity, trough viscosity as well as final viscosity from 1382 to 1708 , 926.7 to1314.3, and 1810.7 to $2092 \mathrm{RVU}$, respectively. While, setback viscosity decreased from 883.70 to $780.00 \mathrm{RVU}$ as the level of wheat substitution increased. The sensory quality of the cookies were not significantly different at all levels of incorporation except crispness that was reduced significantly $(\mathrm{p}<0.05)$ after $30 \%$ substitution.
\end{abstract}

Keywords: Cookies, Sorrel, Cassava, Composite Flour

\section{INTRODUCTION}

Composite flour has often been used with the intent of reducing importation of wheat and improving its nutritional value, most especially in countries where, wheat crop is not grown. The use of composite flour also promotes the use of some locally cultivated crops as flour and increases the nutritional content of food products (Hasmad et al., 2014). Wheat as a cereal crop is as far as nutrient is concerned poor, as it is lacking in some limiting amino acids, such as lysine and threonine, even though it is considered as good source of calories and other nutrients. Compositing wheat flour with locally available, avoidable flours from, other cereals and legumes has successfully increased its nutritional quality (Nilufer et al., 2008). The growing large market for confectioneries and pastries has encouraged local raw materials replacement for wheat (Nooz-Aziah and Komath , 2009). Also governments in developing countries are encouraging policies aimed at assessing the possibility of using alternative local sources of flour as substitute for wheat flour (Abdelghafor et al., 2001). Cookies as confectionary edible products are widely eaten in Nigeria, most especially among kids and young people. It is cheap to purchase and has longer shelf life when compared with other processed foods (Oyeyinka et al., 2014).

Wheat has been tagged as the number three most important cereal crop after maize and rice. It is one of the most essential staple foods for man (Akhtar et al. 2008). It is also the most abundantly available energy grain for the production of confectioneries, as it is a cheaper source of protein and carbohydrates. It has a unique protein (gluten) that makes it adequate for the production of cookies, pastries and bread, because of the strength and elasticity it provides. (Akhtar et al., 2008). Meanwhile, wheat is not at the moment grown in commercial quantity in Nigeria. Most of the wheat used for confectionaries are imported, which impose a considerable foreign exchange burden on the country's economy. Hence, the need for the use of composite flour from home grown sources for the production of some of the confectioneries consumed in the country.

Sorrel seed has a high protein content when compared to other seeds and are abundantly grown in many countries of Africa and Asia. Plant proteins have been extensively recognized as important sources of affordable protein. Studies have shown that Sorrel seeds can be used as a possible source of proteins (Tounkara et al., 2011). Sorrel seeds protein isolate or concentrates could be a veritable source of cheap protein replacement in dietary supplement or as ingredients for food companies (Sanni et al., 2019). It use, could lessen pressure on conventional sources like, meat, fish and soybean. Cassava is an important root crop and a major energy food for more than half a billion people in the third nations of world (Falade, 2010). Yellow cassava, a variety of cassava naturally high in pro vitamin $\mathrm{A}$, has been developed and introduced into Africa by the International Institute of Tropical Agriculture (IITA) in Nigeria. The color of the tuber ranges from deep yellow to slightly orange. Carotenoids concentration is a stable trait and is influenced more by genotype than by its environment (Maroya et al., 2012). Even though yellow cassava is an excellent source of $\beta$-carotene and energy, it is generally poor in other nutrients such as protein, fat, iron and zinc. Children, whose diets consist mainly of cassava, even it elevated carotenoids, may still be vulnerable to micronutrient deficiencies (Joy et al., 2014). Therefore, the use of yellow cassava, will require additional food-based dietary nutrients to make up for the existing gap in nutrients in the diet.

Newly developed, High quality cassava flour (HQCF) is a good alternative for wheat flour substitution. Meanwhile, it has to meet the quality features in terms of nutritional and chemical characteristics, and cyanogenic glucoside content (Adetuyi et al., 2009). HQCF has been showed to be useful for many applications at homes, for the production of various types of pastries and confectionery foods at cities and as raw material for the manufacture of industrial products (Iwe et al., 2014). Soybean, sunflower seeds chickpea and broad bean protein isolate to mention but few have been used as sources of high quality protein for cookies and biscuits production (Modsen et al., 2009; Lee and Brennand, 2005; Claughton and Pearce 1998; Rababah et al., 2006). Sorrel seeds are far less expensive than many of these seeds, and so could be a cheaper source of protein for composite flour. This research was therefore aimed at investigating the effect of sorrel seed protein isolate and yellow cassava flour 
fortification on the nutritive value and sensory properties of cookies thus producing an inexpensive, nutritionally balanced food.

\section{MATERIAL AND METHODS}

\section{Materials Collections}

High Quality Cassava Flour (HQCF) made from yellow flesh cassava (TMS/BA/1368) was collected from International Institute of Tropica Agriculture (IITA), Ibadan, Oyo state. Sorrel seeds were bought at Kaduna central market, Kaduna state, Nigeria. Other raw materials and ingredients such as whole wheat grains, baking powder, flavour, sugar, eggs, butter and the packaging materials were obtained from Ikole market in Ikole-Ekiti, Ekiti State.

\section{Preparation of Wheat Flour}

Whole wheat seeds were sorted and cleaned by the removal of plant debris, dust and stone. The seeds were milled using a laboratory scale hammer miller (Model 9FQ-320) and the powder gotten was sieved through $0.25 \mathrm{~mm}$ screen.

\section{Preparation of Sorrel Seed Protein Isolate}

Sorrel flour was first defatted using Soxhlet apparatus (Ginotec, China). A modified method of Gbadamosi et al., (2012) was used for the preparation of protein isolates from sorrel flour. The sorrel seeds flour was first defatted for 6 hours using a Soxhlet apparatus after which $100 \mathrm{~g}$ of the defatted flour was suspended in water in the ratio 1:10 and it was stirred in a magnetic stirrer for 10 min and the $\mathrm{pH}$ was adjusted to 10.0 and stirred for $4 \mathrm{~h}$ at constant $\mathrm{pH}$. The slurry was centrifuged at $4500 \mathrm{rpm}$ for $30 \mathrm{~min}$ at ambient temperature $\left(25 \pm 2^{\circ} \mathrm{C}\right)$. The supernatant was collected and the $\mathrm{pH}$ was brought to 4.5 to precipitate the protein. The mixture was centrifuged at $4500 \mathrm{rpm}$ for $30 \mathrm{~min}$, the residue obtained was washed twice with distilled water, re-suspended in distilled water and the $\mathrm{pH}$ was adjusted to 7.0 (neutral) after which it was centrifuged at 4500 $\mathrm{rpm}$ for $10 \mathrm{~min}$. The residue was lyophilized or freeze dried (Model LGJ-10) to obtain isolate.

\section{Preparation of Cookies}

Four flour blends were prepared from wheat, sorrel seed protein isolate and yellow cassava flours according to the formulation presented in Table 1 . The cookies were produced, using to the method reported by Ndife et al. (2014) with some modifications. The dry components were first mixed together (composite flour, sugar, baking powder) then the wet parts were mixed also (eggs, butter, milk, flavor). The wet components were added to the dried one and kneaded for about $10 \mathrm{~min}$ into fine dough. The dough gotten, was cut into uniform sizes and shapes and made to passed through a series of molding, shaping and stamping. The stamped dough was baked in the oven (Model DHG-9023A) for $20 \mathrm{~min}$ at $185{ }^{\circ} \mathrm{C}$, the products were left to cool and were then packaged with a nylon wrappers. The produced cookies were kept at cool dried place until required for further analysis.

Table 1 Formulation of composite Flour for cookies production

\begin{tabular}{|c|c|c|c|c|}
\hline \multirow[b]{2}{*}{ Ingredient } & \multirow[b]{2}{*}{$\mathrm{W}_{100: 0: 0}$} & \multicolumn{3}{|c|}{ Blends } \\
\hline & & $\mathrm{W}_{85: 5: 10}$ & $\mathrm{~W}_{70: 10: 20}$ & $\mathrm{~W}_{55: 15: 30}$ \\
\hline Wheat $(\%)$ & 100 & 85 & 70 & 55 \\
\hline $\begin{array}{l}\text { Sorrel Seed Protein } \\
\text { Isolate }(\%)\end{array}$ & - & 5 & 10 & 15 \\
\hline $\begin{array}{ll}\text { Yellow } & \text { Cassava } \\
\text { Flour }(\%) & \end{array}$ & - & 10 & 20 & 30 \\
\hline Margarine (g) & 50 & 50 & 50 & 50 \\
\hline Sugar $(g)$ & 40 & 40 & 40 & 40 \\
\hline Vanilla Flavour (g) & 1 & 1 & 1 & 1 \\
\hline $\begin{array}{l}\text { Powdered Filled Milk } \\
(\mathrm{g})\end{array}$ & 11 & 11 & 11 & 11 \\
\hline Baking Powder (g) & 1 & 1 & 1 & 1 \\
\hline $\operatorname{Egg}(g)$ & 5 & 5 & 5 & 5 \\
\hline $\begin{array}{l}\text { Total weight of } \\
\text { Dough }(\mathrm{g})\end{array}$ & 204 & 204 & 204 & 204 \\
\hline
\end{tabular}

\section{Proximate Analysis of Cookie Samples}

Proximate composition of the cookies sample were evaluated using standard methods of AOAC (2005). The carbohydrate was calculated by difference, while energy content (E) was calculated using the Atwater factor (Obiegbuna and Baba, 2001) as: $\mathrm{E}(\mathrm{Kcal} / 100 \mathrm{~g})=(4 \mathrm{X} \mathrm{P})+(9 \mathrm{XF})+(4 \mathrm{XC})$ where $\mathrm{E}$ is energy, $\mathrm{P}$ is Protein F is Fat and $\mathrm{C}$ is Carbohydrates
Determination of Functional and physical properties of the Composite Flour

\section{Water and Oil Absorption Capacity}

The Water and Oil absorption capacities were determined at room temperature using method of Onwuka, (2005)

\section{Determination of Bulk Density}

Bulk density (loose and packed) was determined by the method of Onwuka (2005). For Packed bulk density, $10 \mathrm{ml}$ graduated cylinder, initially tarred, was carefully filled with the sample. The base of the cylinder was gently tapped on a laboratory bench several times till there was no further attenuation of the sample level after filling to the $10 \mathrm{ml}$ mark. For loose bulk density, an empty and dried $100 \mathrm{ml}$ measuring flask was weighed and flour sample was left to fall freely into it up to the mark. The flask was weighed again along with the sample. Bulk density (loose and packed) was evaluated as weight of sample per unit volume of sample $(\mathrm{g} / \mathrm{ml})$.

$$
\text { Bulk density }(\mathrm{g} / \mathrm{mL})=\frac{\text { Weight of sample }}{\text { Volume of sample after tapping }}
$$

\section{Determination of $\mathrm{pH}$}

The $\mathrm{pH}$ of the samples were determined by making a $10 \% \mathrm{w} / \mathrm{v}$ suspension of the sample in distilled water. The suspensions were thoroughly mixed and the $\mathrm{pH}$ evaluated with a Hand held $\mathrm{pH}$ meter (HANNA, pH; Model Scholar 425), (Onwuka, 2005).

\section{Determination of Swelling Capacity}

The swelling capacity was assessed by the method presented by Rosell et al (2009) with modifications. The sample was fill into $100 \mathrm{ml}$ graduated cylinder to $10 \mathrm{ml}$ mark. Then the cylinder was filled with distilled water arrive at a tota volume of $50 \mathrm{ml}$. The top of the graduated cylinder was tightly covered and mixed by inverting the cylinder. The suspension was inverted again after 2 minutes and left to stand for $60 \mathrm{~min}$. The swelling capacity of the sample was evaluated as an increase in the original volume.

Swelling Capacity $(\mathrm{mL} / \mathrm{g})=\frac{\text { Volume Occupied by Sample }}{\text { Original Sample Weight }}$

\section{Determination of Foaming Capacity}

Foaming capacity of the flour samples were evaluated according to the AOAC (2005) method. Sample of $2 \mathrm{~g}$ was measured from each of the sample and mixed with $100 \mathrm{ml}$ of distilled water at $30 \pm 2^{\circ} \mathrm{C}$ in a graduated cylinder using a warring blender and the suspension was whipped at $1600 \mathrm{rpm}$ for 5 minutes. The mixture was poured into a $100 \mathrm{ml}$ measuring cylinder and its volume was recorded after 30 seconds. Foam capacity was expressed as percentage increase in volume as follows:

Foam Capacity $(\%)=\frac{\text { Volume of foam After whipping-Volume of foam before whipping }}{\text { Volume of foam before whipping }}$

\section{Pasting Characteristics}

The pasting characteristics of whole and composite flour blends were determined using a Rapid Visco Analyser (Newport Scientific Pty Ltd. Warriewood NSW 2102, Australia) hooked on to a workstation. The moisture content of the sample was first determined to obtain the correct sample weight and amount of water required for the test. An aqueous suspension of the sample $(6 \%$, w/w; $28 \mathrm{~g}$ total weight) was prepared and spun at $75 \mathrm{rpm}$. The temperature-time conditions included a heating step from 50 to $100{ }^{\circ} \mathrm{C}$ at $6{ }^{\circ} \mathrm{C} / \mathrm{min}$ (after an equilibration time of $1 \mathrm{~min}$ at $50{ }^{\circ} \mathrm{C}$ ), a holding phase at $100{ }^{\circ} \mathrm{C}$ for $5 \mathrm{~min}$, cooling step from 100 to $50{ }^{\circ} \mathrm{C}$ for $2 \mathrm{~min}$. Viscosity was expressed in centipoises (cP) (IITA, 2001).

\section{Carotenoids Determination}

The total content of carotenoids in the cookies samples was evaluated using a method of Rodriguez-Amaya and Kimura, (2004). $15 \mathrm{~g}$ of the samples, plus $3 \mathrm{~g}$ of celite 454 (Tedia, Ohio, USA) was weighed on a digital balance (Bel Engineering, model MA0434/05). For the carotenoid, gradual additions of $25 \mathrm{~mL}$ of acetone were done to arrive at a paste, that is put into a sintered funnel $(5 \mu \mathrm{m})$ joined to a $250 \mathrm{~mL}$ Buchner flask and filtered under vacuum. This step was repeated thrice until the sample turned colorless. The extract gotten was poured into a $500 \mathrm{~mL}$ separating funnel that has $40 \mathrm{~mL}$ of petroleum ether. The acetone was gotten rid of through a stepwise addition of ultrapure water (Milli-Q Millipore) to hinder the formation of emulsion. The aqueous phase was thrown off. This procedure was repeated four times till there was no residual solvent remaining. The extract was transferred via a funnel to a $50 \mathrm{~mL}$ volumetric flask that has $15 \mathrm{~g}$ of anhydrous sodium sulfate. The volume was made up by 
petroleum ether, and the samples were evaluated by a spectrophotometer that was set at $450 \mathrm{~nm}$. The total carotenoid content was determined using the formula stated thus:

Carotenoids Content $(\mu \mathrm{g} / \mathrm{g})=\frac{A \times V(m L) \times 10^{4}}{\mathrm{~A} 1 \% 1 \mathrm{~cm} \times \mathrm{P}(\mathrm{g})}$

Where $\mathrm{A}=$ Absorbance; $\mathrm{V}=$ Total extract volume; $\mathrm{P}=$ sample weight; $\mathrm{A}^{1 \%}{ }_{1 \mathrm{~cm}}$ $=2592$ ( $\beta$-carotene Extinction Coefficient in petroleum ether).

\section{Mineral Analysis}

The analyses for essential mineral elements Potassium (K), Sodium (Na), Zinc $(\mathrm{Zn})$, Iron $(\mathrm{Fe})$ and Calcium $(\mathrm{Ca})$ were investigated using atomic absorption spectrophotometer for $\mathrm{Ca}, \mathrm{Zn}, \mathrm{Fe}$ while flame photometric method was used for Potassium (K) and Sodium (Na) (AOAC,2005). About $0.5 \mathrm{~g}$ of the sample was weighed into a digestion flask and $10 \mathrm{~mL}$ of nitric acid and $10 \mathrm{~mL}$ of $\mathrm{HCl}$ were added. The mixture was digested for $10 \mathrm{~min}$. The digested mixture was filtered using No 1 whatman filter paper. The filtrate was made up to $50 \mathrm{~mL}$ with distilled water. An aliquot was transferred to the flame Spectrophotometer (Perkin Elmer, model 402) at $420 \mathrm{~nm}$.

\section{Sensory Analysis}

The sensory profile of the cookies was evaluated by 20 semi-trained panelist selected from students using a 9-point hedonic scale from like extremely (9) to dislike extremely (1). Quality parameters evaluated were taste, colour, flavor/aroma, texture, appearance, crispiness and overall acceptability as described by Iwe (2010).

The panelists were University Students screened for familiarity with the product Sessions were conducted at the Federal University, Oye-Ekiti, Ikole-Ekiti and the language used for the sensory testing was English. Water was served to rinse the mouth between samples testing.

\section{Statistical Analysis}

Data were analysed using Analysis of Variance ANOVA and mean separated by New Duncan Multiple range test using Snedector and Cochram (1976). Significance was accepted at $5 \%$ level of probability.

\section{RESULTS AND DISCUSSION}

\section{Functional and Physical Properties of the Flour Samples}

The results of the functional properties of the composite flour blends are summarized in Table 3. There were significant differences $(p<0.05)$ in the swelling capacity, water absorption capacity, oil absorption capacity, packed bulk density and loose bulk density of the flour samples.

The water absorption capacity of the flour samples varied from $0.83 \mathrm{~g} / \mathrm{g}$ in $\mathrm{W}_{100: 0: 0}$ to $1.34 \mathrm{~g} / \mathrm{g}$ in $\mathrm{W}_{55: 15: 30}$. Water absorption capacity increased with increasing replacement of wheat flour with sorrel seed protein isolate and yellow cassava flour due to the addition of sorrel seed protein isolate. The increase in water absorption capacity of composite flours means the composite flours absorbed water greatly compared to wheat flour. As similarly observed by Adebowale et al.(2008), water holding capacity of wheat-soybeans-banana flours increased with soy-banana flour substitution due to increase in protein content because addition of soy and banana flour to the wheat flour makes it to have high water absorption capacity which in turn improves the reconstitution and textura abilities obtainable from the wheat flour. Water absorption capacity is essential in bulking and consistency of product and in baking applications (Niba, et al., 2002). Ndulaka and Obasi, (2018) reported that high WAC as recorded in this study will be very useful in bakery products, and that it could prevent staling by reducing moisture loss.

The oil absorption capacity (OAC) of the flour samples also ranged from $0.96 \mathrm{~g} / \mathrm{g}$ in $\mathrm{W}_{100: 0: 0}$ to $1.23 \mathrm{~g} / \mathrm{g}$ in $\mathrm{W}_{55: 15: 30}$. Oil absorption capacity increased with increasing substituting of wheat flour with sorrel protein isolate and yellow cassava flour. Oil absorption capacity (OAC) is the ability of flour to absorb oil, which is important as oil acts as flavor retainer and improves mouth feel (Onimawo et al., 2001). The high OAC suggests the lipophilic nature of the constituents of the flour (Ubor and Akobundu, 2009), and this suggests that the blends are potentially useful in structural interaction in food especially in flavor retention, improvement of sensory quality, and shelf life extension of of bakery or meat products (Ndulaka and Obasi, 2018).

The packed bulk density of the flour samples varied from $0.63 \mathrm{~g} / \mathrm{ml}$ in W55:15:30 to $0.81 \mathrm{~g} / \mathrm{ml}$ in W100:0:0. Packed bulk density was seen to increase as the level of wheat flour substitution with sorrel seed protein isolate and yellow cassava flour increased. Loose bulk density of the flour samples varied from 0.57 $\mathrm{g} / \mathrm{ml}$ in W55:15:30 to $0.77 \mathrm{~g} / \mathrm{ml}$ in W100:0:0 showing that, loose bulk density increased with increasing replacement of wheat flour with sorrel seed protein isolate and yellow cassava flour. It has been well established tha bulk density of a food material is essential in relation to its packaging. The result obtained from this study indicates that more the cookies could be packaged in constant volume which ensures an economical packaging. It is also said that elevated bulk density nutritionally promotes adequate digestibility, especially among kids who have immature digestive system diseases. Thus, it could be considered a snack for children (Henry et al., 2016). Udensi and Eke,(2000) also indicated that high bulk density is desirable when ease of dispersibility and paste reduction are of consideration.

The swelling capacity of the flour samples varied from $17.17 \mathrm{ml} / \mathrm{g}$ in W100:0:0 to $20.00 \mathrm{ml} / \mathrm{g}$ in $\mathrm{W} 55: 15: 30$. Swelling capacity increased with increasing replacement of wheat flour with sorrel seed protein isolate and yellow cassava flour. Several authors have reported that inherent flour lipid restrict swelling because of it interactions with amylose in the flour starch (Putseys et al., 2010 Oyeyinka et al., 2016b). Lipid also chelate the surface of starch with film, which hinder swelling and hydration(Kim and Walker, 1992). High swelling index according to Achinewhu et al. (1998) enables good thickening and bulking agent This result indicates that the substitution of wheat flour with sorrel protein isolate and yellow cassava flour increased the swelling capacity. Hence, small flour quantity may be required to produce cookies from these composite flour compared to $100 \%$ wheat flour.

Foaming capacity of the flour samples ranged from $11.17 \%$ in $\mathrm{W}_{100: 0: 0}$ to $16.00 \%$ in $\mathrm{W}_{55: 15: 30}$. Foaming capacity got elevated with increasing substituting of wheat flour with sorrel seed protein isolate and yellow cassava flour. The increase in foaming capacity is due to increase substitution of wheat flour with sorrel seed protein isolate and yellow cassava flour and can be related to maintenance of protein structure. For a protein to have excellent foaming properties, it has to be very soluble. Because foam capacity demands rapid adsorption of protein at the air/water interface during whipping penetration into the surface layer and re-arrangement at the interface (Amon et al., 2011). Foams are used to improve texture, consistency and appearance of foods (Akubor, 2003). The $\mathrm{pH}$ of the cookies ranged from 5.43 in $\mathrm{W}_{55: 15: 30}$ to 6.32 in $\mathrm{W}_{\text {100:0:0 }}$. The $\mathrm{pH}$ of the cookies decreased with increasing replacement of wheat flour with sorrel protein isolate and yellow cassava flour. The inclusion sorrel seed isolate and yellow cassava lowers the $\mathrm{pH}$ of the cookies made from the blended flour. In food some sensitive biological parameter such as gut' homeostasis, microbial growth on food, and feeding behavior could be affected by changes in $\mathrm{pH}$. Hence, variation in the acidity of the cookie will affect their sensory attributes, taste and storage stability.

Table 2 Functional and Physical Properties of the Flour Samples

\begin{tabular}{llllllll}
\hline Sample & $\begin{array}{l}\text { Water } \\
\text { absorption } \\
\text { capacity } \\
(\mathrm{g} / \mathrm{g})\end{array}$ & $\begin{array}{l}\text { Oil } \\
\text { absorption } \\
\text { capacity } \\
(\mathrm{g} / \mathrm{g})\end{array}$ & $\begin{array}{l}\text { Packed } \\
\text { bulk } \\
\text { density } \\
(\mathrm{g} / \mathrm{g})\end{array}$ & $\begin{array}{l}\text { Loose } \\
\text { bulk } \\
\text { density } \\
(\mathrm{g} / \mathrm{ml})\end{array}$ & $\begin{array}{l}\text { Swelling } \\
\text { capacity } \\
(\mathrm{ml} / \mathrm{g})\end{array}$ & $\begin{array}{l}\text { Foaming } \\
\text { capacity } \\
(\%)\end{array}$ & $\mathrm{pH}$ \\
\hline $\mathrm{W}_{100: 0: 0}$ & $0.83 \pm 0.01^{\mathrm{d}}$ & $0.96 \pm 0.01^{\mathrm{c}}$ & $0.81 \pm 0.01^{\mathrm{a}}$ & $0.77 \pm 0.01^{\mathrm{a}}$ & $17.17 \pm 0.17^{\mathrm{b}}$ & $11.17 \pm 0.17^{\mathrm{d}}$ & $6.32 \pm 0.07^{\mathrm{a}}$ \\
$\mathrm{W}_{85: 5: 10}$ & $0.93 \pm 0.01^{\mathrm{c}}$ & $1.05 \pm 0.03^{\mathrm{b}}$ & $0.71 \pm 0.01^{\mathrm{b}}$ & $0.68 \pm 0.01^{\mathrm{b}}$ & $18.00 \pm 0.58^{\mathrm{ab}}$ & $12.50 \pm 0.29^{\mathrm{c}}$ & $5.94 \pm 0.04^{\mathrm{b}}$ \\
$\mathrm{W}_{70: 10: 20}$ & $1.06 \pm 0.02^{\mathrm{b}}$ & $1.07 \pm 0.02^{\mathrm{b}}$ & $0.66 \pm 0.01^{\mathrm{c}}$ & $0.62 \pm 0.01^{\mathrm{c}}$ & $19.00 \pm 0.58^{\mathrm{ab}}$ & $14.50 \pm 0.29^{\mathrm{b}}$ & $5.56 \pm 0.03^{\mathrm{c}}$ \\
$\mathrm{W}_{55: 15: 30}$ & $1.34 \pm 0.02^{\mathrm{a}}$ & $1.23 \pm 0.02^{\mathrm{a}}$ & $0.63 \pm 0.01^{\mathrm{d}}$ & $0.57 \pm 0.01^{\mathrm{c}}$ & $20.00 \pm 0.58^{\mathrm{a}}$ & $16.00 \pm 0.00^{\mathrm{a}}$ & $5.43 \pm 0.06^{\mathrm{c}}$ \\
\hline
\end{tabular}

Values are mean \pm S.D. Means with same superscript across a column are not significantly $(\mathrm{p}>0.05)$ different.

\section{Pasting profile of composite flours}

The results of the pasting properties of the composite flour samples are presented in Table 5. There were significant $(\mathrm{p}<0.05)$ differences in the pasting profile of the flour samples for peak viscosity, trough viscosity, breakdown, final viscosity, setback viscosity, peak time and pasting temperature. Olatunde et al. (2016) has also reported that pasting characteristics such as peak viscosity, pasting temperature and setback viscosity of the composite flours differed significantly in cassava-wheat Composite flour biscuit.
Peak viscosity of the flour samples ranged from 1382 RVU in $\mathrm{W}_{100: 0: 0}$ to

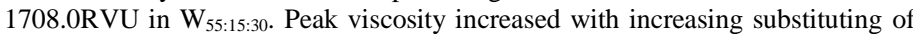
wheat flour with sorrel protein isolate and yellow cassava flour. It has been reported that pasting viscosity of the flours generally get elevated with increase in the pro-vitamin A cassava flour (Olatunde et al., 2016). Peak viscosity of flours is controlled by quiet a lot of factors namely, amylose content, granular size of starch, fats and proteins. During the cooking of flours, amylose in starch leaches out into the surrounding medium to form a viscous paste. The extent of association between the various constituents of 
the flours may explain the reason for the differences in the paste peak viscosity observed. The elevated starch content in cassava flour may have supported the increased peak viscosity of the blended flours.

Trough viscosity of the flour samples ranged from $926.7 \mathrm{RVU}$ in $\mathrm{W}_{100: 0: 0}$ to

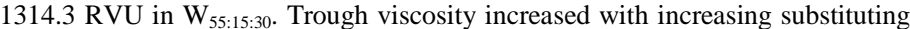
of wheat flour with sorrel protein isolate and yellow cassava flour. Olapade and
Adeyemo (2014) also reported that trough also increased as cassava flour increased in cassava, cowpea and wheat flour cookies. They also said that trough is the lowest viscosity value in the constant temperature phase of the RVA profile and it measures the capaability of the paste to restrict breakdown while undergoing cooling.

\begin{tabular}{|c|c|c|c|c|c|c|c|}
\hline Sample & $\begin{array}{l}\text { Peak viscosity } \\
\text { (RVU) }\end{array}$ & $\begin{array}{l}\text { Trough } \\
\text { viscosity } \\
\text { (RVU) }\end{array}$ & $\begin{array}{l}\text { Breakdown } \\
\text { viscosity } \\
\text { (RVU) }\end{array}$ & $\begin{array}{l}\text { Final viscosity } \\
\text { (RVU) }\end{array}$ & $\begin{array}{l}\text { Setback } \\
\text { viscosity } \\
\text { (RVU) }\end{array}$ & $\begin{array}{l}\text { Peak time } \\
(\mathrm{min})\end{array}$ & $\begin{array}{l}\text { Pasting } \\
\text { temperature } \\
\left({ }^{\circ} \mathrm{C}\right)\end{array}$ \\
\hline$\overline{\mathrm{W}_{100: 0: 0}}$ & $1382.0 \pm 0.00^{\mathrm{d}}$ & $926.7 \pm 0.33^{\mathrm{d}}$ & $455.3 \pm 0.33^{\mathrm{a}}$ & $1810.7 \pm 0 .{ }^{33 d}$ & $883.7 \pm 0.33^{\mathrm{c}}$ & $5.32 \pm 0.01^{b}$ & $70.10 \pm 0.00^{\circ}$ \\
\hline $\mathrm{W}_{85: 5: 10}$ & $1445.3 \pm 0.33 c$ & $1021.7 \pm 0.33^{\mathrm{c}}$ & $423.0 \pm 0.58^{b}$ & $2050.3 \pm 0.33^{c}$ & $1028.0 \pm 0.58^{\mathrm{a}}$ & $5.51 \pm 0.01^{\mathrm{a}}$ & $84.60 \pm 0.06^{\mathrm{a}}$ \\
\hline $\mathrm{W}_{70: 10: 20}$ & $1649.0 \pm 0.58^{b}$ & $1238.0 \pm 0.58^{b}$ & $410.3 \pm 0.33^{c}$ & $2188.0 \pm 0.58^{\mathrm{a}}$ & $951.0 \pm 0.58^{\mathrm{b}}$ & $5.51 \pm 0.01^{\mathrm{a}}$ & $84.77 \pm 0.03^{b}$ \\
\hline $\mathrm{W}_{55: 15: 30}$ & $1708.0 \pm 0.58^{\mathrm{a}}$ & $1314.3 \pm 0.33^{\mathrm{a}}$ & $395.3 \pm 0.33^{\mathrm{d}}$ & $2092.0 \pm 0.58^{b}$ & $780.0 \pm 0.58^{\mathrm{d}}$ & $5.46 \pm 0.00^{\mathrm{ab}}$ & $75.04 \pm 0.00^{\mathrm{c}}$ \\
\hline
\end{tabular}

Values are mean \pm S.D. Means with same superscript across a column are not significantly ( $>0.05)$ different.

Breakdown viscosity of the flour samples are from 395 RVU in $\mathrm{W}_{55: 15: 30}$ to 455.3

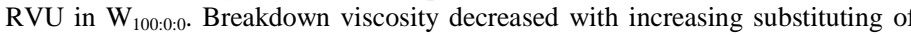
wheat flour with sorrel protein isolate and yellow cassava flour. Olapade and Adeyemo (2014) also reported that breakdown reduced as the cowpea replacement increased from $2476 \mathrm{RVU}$ in $20 \%$ cowpea flour to $1065 \mathrm{RVU}$ in $30 \%$ cowpea flour. The lower breakdown viscosity can be attributed to increase in sorrel seed protein isolate in the composite flour. The more the breakdown in viscosity, the less the ability of the samples to restrict heating and shear stress during cooking (Adebowale and Lawal, 2004). This indicates that cookies made from composite of wheat, sorrel protein isolate and yellow cassava flour will be able to withstand heating and shear stress during cooking than $100 \%$ wheat flour. Final viscosity of the flour samples ranged from 1810.7 RVU in $\mathrm{W}_{100: 0: 0}$ to 2092.0 RVU in $\mathrm{W}_{55: 15: 30}$. Final viscosity increased with increase wheat flour subtitution with sorrel protein isolate and yellow cassava flour. Setback viscosity of the flour samples ranged from 780.0 RVU in $\mathrm{W}_{55: 15: 30}$ to $1028.0 \mathrm{RVU}$ in $\mathrm{W}_{85: 5: 10}$. Setback viscosity initially increased with increasing replacement of wheat flour with sorrel seed protein isolate $(5 \%)$ and yellow cassava flour $(10 \%)$ then decreased significantly with increasing substituting of wheat flour with sorrel protein isolate and yellow cassava flour. Olatunde et al. (2016) found that setback viscosity of the flour reduced from 1255 to 890 RVU with increase in the levels of cassava flour pro-vitamin A. Setback viscosity is an expression of the retrogradation propensity of cooked starch, which relied on the extent of reassociation of leached amylose. The decrease in setback viscosity following the addition of provitamin A cassava flour suggest low retrogradation propensity of the blended flours.

Peak time of the flour samples ranged from $5.32 \mathrm{~min}$ in $\mathrm{W}_{100: 0: 0}$ to $5.51 \mathrm{~min}$ in $\mathrm{W}_{70: 10: 20}$. Peak time increased with increasing replacement of wheat flour with sorrel protein isolate and yellow cassava flour. Pasting temperature of the flour samples ranged from $70.10{ }^{\circ} \mathrm{C}$ in $\mathrm{W}_{100: 0: 0}$ to $84.77{ }^{\circ} \mathrm{C}$ in $\mathrm{W}_{70: 10: 20}$. Pasting temperature decreased with increasing substituting of wheat flour with sorre protein isolate and yellow cassava flour. Pasting temperature gives an indication of the lowest temperature required to cook the flour and also shows the ease of cooking. This indicates that cookies made from composite of wheat, sorrel protein isolate and yellow cassava flour will require more time to cook compared to cookies made from $100 \%$ wheat flour. This does not agree with the findings of Olatunde $\boldsymbol{e t}$ al. (2016) where the pasting temperature $\left(87.25^{\circ} \mathrm{C}\right)$ of wheat flour $(100 \%)$ was higher than that of blended flour (wheat and pro-vitamin A cassava flour), which was approximately $74{ }^{\circ} \mathrm{C}$. The differences in the results might be as result of the presence of elevated protein content in the sorrel protein isolate.

\section{Proximate and Carotenoids Composition of the Cookies}

The results of the chemical composition of the cookies are presented in Table 2. There were significant differences $(p>0.05)$ in the moisture content, ash, crude fat, carbohydrate, protein, carotenoid and crude fiber content of the cookies. Moisture content of the cookies ranged from $5.17 \%$ in $\mathrm{W}_{55: 15: 30}$ to $6.67 \%$ in
$\mathrm{W}_{\text {100:0:0 }}$ which was relatively low. Cookies are generally low moisture foods (Ndulaka and Obasi, 2018). Moisture content reduced with increasing substituting of wheat flour with sorrel seed protein isolate and yellow cassava flour. The range of moisture content of the cookies recorded in this research will prolong the shelf-life of these products in storage. Ezeama (2007) and Akhtar et al. (2008) noted that at reduced moisture contents, spoilade of baked products would be reduced due to decreased activity of microorganisms and microbial proliferation will be minimal and it confers higher shelf-life stability to the product. Sengev et al. (2015) submitted that the moisture content of cookies from composite flours of wheat, sweet potato and mango seeds flour increased significantly $(\mathrm{p}<0.05)$ with increase in the level of substitution which is alluded to the hygroscopic nature of mango seeds flour due to the presence of reducing sugars. Crude protein content of the cookies ranged from $14.29 \%$ in $\mathrm{W}_{\text {100:0:0 }}$ to $23.12 \%$ in $\mathrm{W}_{55: 15: 30}$. Crude protein content increased with increasing replacement of wheat flour with sorrel protein isolate and yellow cassava flour. It is expected that the protein content of the cookies produced from blended flour of wheat and cassava to reduce, as reported by Olapade and Adeyemo (2014), that, increase in the levels of cassava flour substitution of wheat flour resulted in a decrease in the protein content progressively, which was attributed to the low protein content of the cassava flour. Olatunde $\boldsymbol{e t}$ al. (2016) also showed that inclusion of provitamin A cassava flour to wheat flour showed a reduction in protein content of biscuits which is also similar to what was reported on composite biscuits by Hooda and Jood (2005); Oluwamukomi et al. (2011); Oyeyinka et al. (2014) However, high protein composition as observed in this work despite the substitution of wheat flour with yellow cassava flour, can only be attributed to the addition of sorrel seed protein isolate.

Hainida et al. (2008) discovered high protein content in sorrel seeds and protein content of the sorrel seeds is higher than that of other common seeds and grain legumes. Flour made from sorrel seeds flour contain a high amount of protein $(27 \%)$ while sorrel seed protein isolate showed high protein content $(88 \%)$ (Ismail et al., 2008). Hence, sorrel protein isolate can serve the complementary purpose in development of protein-rich cookies. Similar observation was made when soybean was composited with wheat flour by Atobatele and Afolabi, (2016), Other studies have also reported a similar increase of protein content in soy-composite flours (Mashayekh et al., 2008). Sorrel protein isolate-fortified cookies will be of nutritional importance in most third world countries like Nigeria where majority of family can hardly afford high protein foods because of their exorbitant prices (Falola et al., 2014) thereby help in preventing diseases such as kwashiorkor that results from higher carbohydrate intake. The sorrel protein isolate from sorrel seed is $94.67 \%$. This indicates a very high composition of crude protein in the isolate. This result corroborates the reasons for the usage of sorrel because of its high protein content which is readily available and can easily substitute or supplement animal source of protein (Sanni et al., 2016). Sorrel seeds are valuable food source, when its protein, calories, fiber and micronutrients contents are put into consideration.

Table 4 Chemical Composition of the Cookies

\begin{tabular}{lllllllll}
\hline Sample & $\begin{array}{l}\text { Moisture } \\
\text { content } \\
(\%)\end{array}$ & $\begin{array}{l}\text { Crude } \\
\text { protein } \\
(\%)\end{array}$ & $\begin{array}{l}\text { Crude fat } \\
(\%)\end{array}$ & $\begin{array}{l}\text { Ash } \\
(\%)\end{array}$ & $\begin{array}{l}\text { Crude } \\
\text { fiber } \\
(\%)\end{array}$ & $\begin{array}{l}\text { Carbohydrate } \\
(\%)\end{array}$ & $\begin{array}{l}\text { Energy } \\
(\text { Kcal } / 100 \mathrm{~g})\end{array}$ & $\begin{array}{l}\text { Carotenoids } \\
(\mu \mathrm{g} / \mathrm{g})\end{array}$ \\
\hline $\mathrm{W}_{100: 0: 0}$ & $6.67 \pm 0.17 \mathrm{a}$ & $14.29 \pm 0.14^{\mathrm{d}}$ & $26.67 \pm 0.17^{\mathrm{a}}$ & $1.40 \pm 0.00^{\mathrm{d}}$ & $0.61 \pm 0.01^{\mathrm{d}}$ & $50.37 \pm 0.31^{\mathrm{a}}$ & $498.67 \pm 0.23^{\mathrm{a}}$ & $241.93 \pm 1.10^{\mathrm{d}}$ \\
$\mathrm{W}_{85: 5: 10}$ & $6.00 \pm 0.00^{\mathrm{b}}$ & $16.13 \pm 0.06^{\mathrm{c}}$ & $26.00 \pm 0.00^{\mathrm{b}}$ & $1.63 \pm 0.01^{\mathrm{c}}$ & $0.74 \pm 0.01^{\mathrm{c}}$ & $49.44 \pm 0.01^{\mathrm{a}}$ & $496.28 \pm 0.45^{\mathrm{b}}$ & $301.28 \pm 0.07^{\mathrm{c}}$ \\
$\mathrm{W}_{70: 10: 20}$ & $5.33 \pm 0.17^{\mathrm{c}}$ & $19.24 \pm 0.14^{\mathrm{b}}$ & $25.17 \pm 0.17^{\mathrm{c}}$ & $1.89 \pm 0.01^{\mathrm{b}}$ & $0.88 \pm 0.00^{\mathrm{b}}$ & $47.41 \pm 0.23^{\mathrm{b}}$ & $493.13 \pm 0.13^{\mathrm{c}}$ & $337.95 \pm 0.26^{\mathrm{b}}$ \\
$\mathrm{W}_{55: 15: 30}$ & $5.17 \pm 0.17^{\mathrm{c}}$ & $23.12 \pm 0.06^{\mathrm{a}}$ & $24.17 \pm 0.17^{\mathrm{d}}$ & $1.99 \pm 0.01^{\mathrm{a}}$ & $1.10 \pm 0.01^{\mathrm{a}}$ & $44.39 \pm 0.15^{\mathrm{c}}$ & $487.57 \pm 0.67^{\mathrm{d}}$ & $350.13 \pm 0.10^{\mathrm{a}}$ \\
SPI & - & $94.67 \pm 0.88$ & - & - & - & - & - & - \\
\hline
\end{tabular}

Values are mean \pm S.D. Means with same superscript across a column are not significantly ( $>0.05$ ) different.

Crude lipids composition of the cookies ranged from $24.17 \%$ in $\mathrm{W}_{55: 15: 30}$ to $26.67 \%$ in $\mathrm{W}_{100: 0: 0}$. Crude fat content reduced significantly $(\mathrm{p}<0.05)$ with increasing substitution of wheat flour with sorrel seed protein isolate and yellow cassava flour. In agreement with the findings of this study, Hooda and Jood 
(2005), Oyeyinka et al. (2014) and Olatunde et al. (2016) submitted that the inclusion improved pro-vitamin A cassava flour to wheat flour led to in a decrease in lipid contents of biscuits, while ash and fibre contents increased. They ascribed the decrease in lipid constituents of the biscuits to the decrease in the proportion of wheat flour in the biscuit formulation since wheat flour is a better source of protein and lipid compared to cassava flour, which has most of its constituents as carbohydrate. As similarly observed by Ubor and Akobundu (2009), the fat content of the cookies produced from wheat-cassava-watermelon composite decreased due to the substitution of cassava flour and the reduction of the wheat flour.

Ash constituents of the cookies varied from $1.40 \%$ in $\mathrm{W}_{100: 0: 0}$ to $1.99 \%$ in $\mathrm{W}_{55: 15: 30}$. Ash content increased significantly $(\mathrm{p}<0.05)$ with increasing substitution of wheat flour with sorrel seed protein isolate and yellow cassava flour. Akubor and Badifu (2004) similarly reported in their study that the fibre content increased with increasing level of cowpea flour from $0.65 \%$ in whole African breadfruit kernel flour to $1.50 \%$ wheat, because African Breadfruit seed is relatively high in both ash and fibre. Atobatele and Afolabi (2016) also observed that there was an increase in the ash content of cookies with increasing level of soy-flour in the flour blends. Ash constituent is a representation of mineral content; so samples with high ash constituent are expected to have a relatively high mineral content (Olapade and Adeyemo, 2014).

Crude fiber content of the cookies ranged from $0.61 \%$ in $\mathrm{W}_{100: 0: 0}$ to $1.10 \%$ in

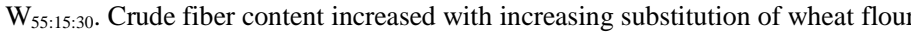
with sorrel protein isolate and yellow cassava flour. As similarly observed by Oluwamukomi et al. (2011), the crude fibre content of composite biscuits increased with substitution of wheat with cassava flour due to the fibre content in the cassava flour which increased in the composite flour. The high fibre and the reduced carbohydrate content of cookies have several health implications, High level of fibre confirmed to aid digestion in the colon and decrease constipation that is often associated with products from refined grain flours (Slavin, 2005). Fibre is good for the body as it improves the stool bulk by acting as a vehicle for faecal water. The fibre content consists of hemicelluloses, cellulose and lignin. It improves the health of the gastro-intestinal system and metabolic system in human (Atobatele and Afolabi, 2016).

The carbohydrate content of the cookies ranged from $44.39 \%$ in $\mathrm{W}_{55: 15: 30}$ to $50.37 \%$ in $\mathrm{W}_{\text {100:0:0. }}$. Carbohydrate content decreased with increasing substitution of wheat flour with sorrel protein isolate and yellow cassava flour. Oluwamukomi et al. (2011) reported that the carbohydrate content initially increased in biscuit produced from composite flours of wheat, cassava, and soy flour as the cassava flour ratio increased. It was also observed that the carbohydrate content of the biscuit reduced again with substitution with $10 \%$ soy flour. The decrease in carbohydrate content may be due to the increase in protein content of the cookies (50.37\% in $\mathrm{W}_{100: 0: 0}$ to $44.39 \%$ in $\mathrm{W}_{55: 15: 30)}$ ). The energy values of the cookies were quite high and significantly different from each other, however with a decrease trend as the level of wheat substation increased. The cookies can be used as energy based snacks (Atobatele and Afolabi, 2016).

Carotenoids content of the cookies ranged from $241.93 \mu \mathrm{g} / \mathrm{g}$ in $\mathrm{W}_{\text {100:0:0 }}$ to

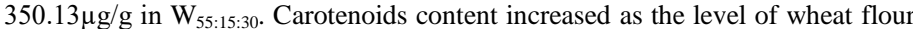
substitution increased with sorrel seed protein isolate and yellow cassava flour. Differences in the carotenoids content of the cookies could be ascribed to different proportion of yellow cassava blends in the cookies. The carotenoids content of compounded biscuits increased as level of pro-vitamin A cassava flour increased in the composite flour from 246.80 to $352.40 \mu \mathrm{g} / 100 \mathrm{~g}$ (Olatunde $\boldsymbol{e t}$ al., 2016). Ndulaka and Obasi (2018) also reported high beta carotene values for cookies produced from blends of wheat flour and biofortified cassava varieties. The consumption of these composite flour cookies under study from yellow cassava flour and wheat blends could reduce Vitamin A Deficiency in kids, pregnant and lactating women and other persons who love to eat cookies to a very large extent. Beta carotene is a major source and precursor of dietary vitamin A to human health (Ndulaka and Obasi, 2018). Adding vitamin A rich cookie-like products to family menu can provide households with direct access to foods rich in $\beta$-carotene and solution to Vitamin A Deficiency (Faber et al., 2002).

\section{Mineral Composition of the Cookies}

Table 4 showed the results of the mineral composition of the cookies. There were significant differences $(p \leq 0.05)$ in the iron, zinc, sodium, potassium and calcium content in the cookies. Iron constituent of the cookies varied from $55.00 \mathrm{mg} / 100 \mathrm{~g}$

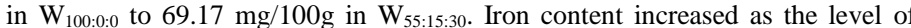
wheat flour substitution with sorrel seed protein isolate increased. Iron is the least abundant mineral component of the cookie composites. Iron is a vital element that must be provided in the diet to prevent anemia and other related diseases (Oluyemi et al., 2008). Based on the WHO (2005) report the daily recommended intake of iron for pregnant/lactating women and children (6-59 months) should be between $5.8 \mathrm{mg} / 100 \mathrm{~g}$ to $27 \mathrm{mg} / 100 \mathrm{~g}$ respectively.

Zinc content of the cookies ranged from $37.17 \mathrm{mg} / 100 \mathrm{~g}$ in $\mathrm{W}_{\text {100:0:0 } 0}$ to 53.00

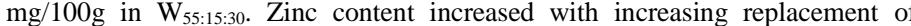
wheat flour with sorrel seed protein isolate and yellow cassava flour. Zinc may be seen as a good source for storage and secretion of insulin from the $\beta$-cell of pancreas; it is also needed for wound healing (Satyanarayana and Chakrapani, 2013). The daily recommended allowance of zinc content for pregnant/ lactating women and children ranged between 10.0 and $4.1 \mathrm{mg} / 100 \mathrm{~g}$, respectively based on WHO (2005), which can be conveniently supplied by fair consumption of any of the cookies formulations

Table 5 Mineral Composition of the Cookies

\begin{tabular}{llllll} 
Sample & Mineral Composition & of the Cookies \\
& $\begin{array}{l}\text { Calcium } \\
(\mathrm{Ca})\end{array}$ & $\begin{array}{l}\text { Iron }(\mathrm{Fe}) \\
(\mathrm{mg} / 100 \mathrm{~g})\end{array}$ & $\begin{array}{l}\text { Zinc }(\mathrm{Zn}) \\
(\mathrm{mg} / 100 \mathrm{~g})\end{array}$ & $\begin{array}{l}\text { Sodium } \\
(\mathrm{Na}) \\
(\mathrm{mg} / 100 \mathrm{~g})\end{array}$ & $\begin{array}{l}\text { Potassium }(\mathrm{K}) \\
(\mathrm{mg} / 100 \mathrm{~g})\end{array}$ \\
\hline $\mathrm{W}_{100: 0: 0}$ & $178.17 \pm 0.17^{\mathrm{d}}$ & $55.00 \pm 0.00^{\mathrm{c}}$ & $37.17 \pm 0.17^{\mathrm{c}}$ & $36.30 \pm 0.58^{\mathrm{d}}$ & $312.70 \pm 1.45^{\mathrm{d}}$ \\
$\mathrm{W}_{85: 5: 10}$ & $218.67 \pm 0.33^{\mathrm{c}}$ & $56.17 \pm 0.17^{\mathrm{c}}$ & $39.17 \pm 0.17^{\mathrm{c}}$ & $38.60 \pm 2.52^{\mathrm{c}}$ & $374.70 \pm 2.03^{\mathrm{c}}$ \\
$\mathrm{W}_{70: 10: 20}$ & $251.67 \pm 0.33^{\mathrm{b}}$ & $62.17 \pm 0.17^{\mathrm{b}}$ & $41.33 \pm 0.17^{\mathrm{b}}$ & $41.40 \pm 1.15^{\mathrm{b}}$ & $409.0 \pm 0.58^{\mathrm{b}}$ \\
$\mathrm{W}_{55: 15: 30}$ & $265.67 \pm 0.33^{\mathrm{a}}$ & $69.17 \pm 0.17^{\mathrm{a}}$ & $53.00 \pm 0.00^{\mathrm{a}}$ & $42.47 \pm 0.58^{\mathrm{a}}$ & $434.70 \pm 3.71^{\mathrm{a}}$ \\
\hline \multicolumn{5}{l}{ Values are mean \pm S.D. Means with same superscript across a column are not significantly $(\mathrm{p}>0.05)$ different. }
\end{tabular}

Calcium content of the cookies ranged from $178.17 \mathrm{mg} / 100 \mathrm{~g}$ in $\mathrm{W}_{\text {100:0:0 }}$ to 265.67 $\mathrm{mg} / 100 \mathrm{~g}$ in $\mathrm{W}_{55: 15: 30}$. Calcium content increased with increasing substituting of wheat flour with sorrel seed protein isolate and yellow cassava flour. Ayo et al. (2010) and Dabels et al. (2016) also showed that calcium and iron increased greatly in composited cookies. Potassium content of the cookies varied from

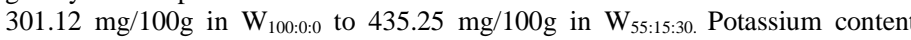
increased as the level of wheat flour subtitution with sorrel seed protein isolate and yellow cassava flour increased.Sodium content of the cookies increased with increasing substitution of wheat flour with sorrel seed protein isolate and yellow cassava flour. Sodium content of the cookies ranged from $36.30 \pm 0.58 \mathrm{mg} / 100 \mathrm{~g}$ in

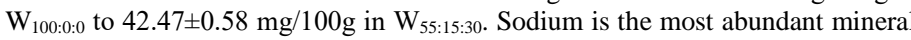
component of the cookie composites. Elemental minerals are required for regular growth, cellular activity and oxygen transport $(\mathrm{Fe})$, fluid balance and nerve transmission $(\mathrm{K})$ as well as the control of blood pressure and strengthening of bones ( $\mathrm{Ca}$ and $\mathrm{K}$ ) (Esan et al., 2017). These results may be due to the high amount of potassium and sodium contained in sorrel seed protein isolate and yellow cassava flour. Since insufficient intakes of micronutrients have been linked with severe malnutrition, increased disease conditions and mental disorder (Wardlaw, 2004), the results from this study showed that the cookies produced from a blended of wheat flour, sorrel protein isolate and yellow cassava flour may contribute significantly to the recommended dietary requirements for minerals in children and adults.

\section{Sensory Attributes of the Cookies}

The results of sensory evaluation are presented in Table 5. The cookies were evaluated for colour, taste, texture, appearance, flavor, crispiness and overall acceptability. Composite cookies produced from $100 \%$ wheat flour do not significantly $(\mathrm{p}>0.05)$ differ from those obtained from $\mathrm{W}_{85: 5: 10}, \mathrm{~W}_{70: 10: 20}$ and $\mathrm{W}_{55: 15: 30}$ in terms of colour, taste, texture, appearance, flavor and overall acceptability. The sensory results from a study by Nwakalor (2014) also indicated that acceptable cookies that were not distinguishable from the control for the most of the sensory attributes were made from $10 \%$ and $20 \%$ substitution wheat flour with Moringa flour for cookies production. Similar to the findings of Ndulaka and Obasi (2018), all the samples had moderately acceptable to extremely acceptable sensory ratings in all the attributes considered which include colour, taste, texture, appearance, flavor, crispiness and overall acceptability. The acceptable sensory properties of the cookies made from wheat flour substitution with sorrel protein isolate and yellow cassava flour were superior to bakery products supplemented with cassava flour evaluated by Mebpa et al. (2007), Olapade and Adeyemo (2014) and Ndulaka and Obasi (2018) indicating that the presence of sorrel protein isolate improved the sensory properties of the cookies.

On the other hand, composite cookies produced from $100 \%$ wheat flour is different significantly $(\mathrm{p} \leq 0.05)$ from $\mathrm{W}_{\text {85:5:10}}, \mathrm{W}_{70: 10: 20}$ and $\mathrm{W}_{55: 15: 30}$ in terms of crispiness. There was decrease in rating of the crispiness of the composite cookies with increase in wheat flour substitution with sorrel protein isolate and yellow cassava flour. Crispiness of the cookies ranged from 7.60 in $\mathrm{W}_{100: 000}$ to

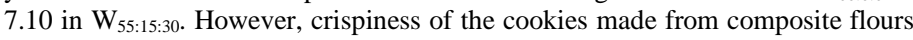


and $100 \%$ wheat flour were moderately acceptable. Reduction in the crispiness of the cookies made from composite flours of sorrel seed protein isolate and yellow cassava flour can be due to lower fat contents of the cookies. Fats have been associated with crispiness of baked foods which impacted flavour and tenderness to the cookies (Akubor et al., 2003; Atobatele and Afolabi, 2016).

\begin{tabular}{|c|c|c|c|c|c|c|c|}
\hline Sample & Colour & Taste & Texture & Appearance & Flavour & Crispiness & $\begin{array}{l}\text { Overall } \\
\text { acceptability }\end{array}$ \\
\hline $\mathrm{W}_{100: 0: 0}$ & $8.10 \pm 0.18^{\mathrm{a}}$ & $7.85 \pm 0.22^{\mathrm{a}}$ & $7.70 \pm 0.25^{\mathrm{a}}$ & $8.40 \pm 0.11^{\mathrm{a}}$ & $7.75 \pm 0.18^{\mathrm{a}}$ & $7.60 \pm 0.25^{\mathrm{a}}$ & $7.68 \pm 0.20^{\mathrm{a}}$ \\
\hline $\mathrm{W}_{85: 5: 10}$ & $7.95 \pm 0.17^{\mathrm{a}}$ & $7.65 \pm 0.25^{\mathrm{a}}$ & $7.65 \pm 0.26^{\mathrm{a}}$ & $8.20 \pm 0.17^{\mathrm{a}}$ & $8.05 \pm 0.17^{\mathrm{a}}$ & $7.45 \pm 0.26^{\mathrm{ab}}$ & $8.05 \pm 0.21^{\mathrm{a}}$ \\
\hline $\mathrm{W}_{70: 10: 20}$ & $8.05 \pm 0.15^{\mathrm{a}}$ & $7.65 \pm 0.28^{\mathrm{a}}$ & $7.70 \pm 0.22^{\mathrm{a}}$ & $8.25 \pm 0.10^{\mathrm{a}}$ & $7.65 \pm 0.15^{\mathrm{a}}$ & $7.20 \pm 0.26^{\mathrm{ab}}$ & $8.21 \pm 0.18^{\mathrm{a}}$ \\
\hline $\mathrm{W}_{55: 15: 30}$ & $8.30 \pm 0.15^{\mathrm{a}}$ & $7.50 \pm 0.20^{\mathrm{a}}$ & $7.70 \pm 0.18^{\mathrm{a}}$ & $8.15 \pm 0.17^{\mathrm{a}}$ & $7.50 \pm 0.24^{\mathrm{a}}$ & $7.10 \pm 0.30^{\mathrm{b}}$ & $8.00 \pm 0.20^{\mathrm{a}}$ \\
\hline
\end{tabular}

Values are mean \pm S.D. Means with same superscript across a column are not significantly ( $\mathrm{p}>0.05)$ different.

\section{CONCLUSION}

Results from this study showed that cookies of acceptable quality can be manufactured from wheat flour, sorrel seed protein isolate and yellow cassava flour. Sorrel seeds protein isolate and yellow cassava supplementation significantly improved the fibre, mineral and pasting characteristics of the cookies. Hence, their incorporation could be used as a protein supplement in special food intervention for malnourished children.

\section{REFERENCES}

ABDELGHAFOR, R. F., MUSTAFA, A. I., IBRAHIM, A. M. and KRISHNAN, P. G. (2011). Quality of bread from composite flour of sorghum and hard white winter wheat. Advance Journal of Food Science and Technology, 3: 9-15. https://maxwellsci.com/print/ajfst/v3-9-15

ACHINEWHU, S.C., BARBER, L.I. AND IJEOMA, I.O. (1998). Physicochemical properties and garrification of selected cassava cultivars in Rivers state. Plant Food Hum. Nutr. Sci., 133 140.https://doi.org/10.1023/A.1008029101710

ADEBOWALE, K. O. AND LAWAL, O. S. (2004). Comparative study of the functional properties of bambarra groundnut (Voandzeia subterranean), jack bean (Canavalia ensiformis) and mucuna bean (Mucuna pruriens) flours. Food $\begin{array}{llll}\text { Research } & \text { International, } & 37 & \text { (4), }\end{array}$ .https://doi.org/10.1016/j.foodres.2004.01.009

ADETUYI, F.O., BADEJO, O.F., IKUJENLOLA, A.V. AND OMOSULI, S.V (2009). Storage influence on the functional properties of malted and unmalted maize (Zea mays L ssp mays) and soybean (Glycine max L Merrill) flour blends. Afr J Food Sci., 3: 56-60. https://www.academicjournal.org/ajfs

AKHTAR, S., ANJUM, F., REHMAN, S., SHEIKH, M., AND FARZENA, K (2008). Effect of fortification on the physico-chemical and microbiological stability of whole wheat flour. Food Chem., 112:156-163. https://doi.org/10.1016/j.foodchem.2008.01.065

AKUBOR, P.I. AND UKWURU, M.U. (2003). 'Functional properties and biscuit making potential of soybean and cassava flour blends' Plant Foods for Human Nutrition, 58:

https://doi.org/10.1023/B.OUAL.0000040344.93438.df

AKUBOR, P.I., AND BADIFU, G.I. (2004) Chemical composition, functional properties and baking potential of African Breadfruit kernel and wheat flour blends. International Journal of Food Science and Technology, 39, 223-229 https://doi.org/10.1046/j.0950.5423.2003.00768.x

AMON, A.S., SORO, Y.R., KOFFI, B.K.P., DUÉ, A.E. AND KOUAMÉ, P.L. (2011). Biochemical characteristics of flours from Ivorian taro (Colocasia esculenta, cv Yatan) corn as affected by boiling time. Advance Journal of Food Science and Technology, 3(6), 424-435. https://maxwellsci.com/print/ajfst/v6-424-435

AOAC, 1995. Official methods of analysis. $16^{\text {th }}$ Edn., Washington. DC. USA: Association of Official Analytical Chemists. https://www.aoac.org/officialmethod-of analysis-16th-1995

ATOBATELE, O. B. AND AFOLABI, M. O., (2016). Chemical Composition and Sensory Evaluation of Cookies Baked from the Blends of Soya Bean and Maize Flours. Applied Tropical Agriculture, Volume 21, No.2 (Special Issue), 8 13,2016

AYO, J. A., IKUOMOLA, D. S., SANNI T. A., ESSON, Y. O., AYO, V. A. AND AJAYI, A. (2010). Evaluation of the nutritional quality of soy-acha composite biscuits.Nigeria Food Journal, 2 (2): 371-385.

CLAUGHTON, S.M. AND PEARCE R.J. (1989) Protein enrichment of sugatsnap cookies with sunflower. Journal of Food Science 54(2),

354-356. https://doi.org/10.1111/j.1365-2621.1998.tb03079.x

DABELS, N., IGBABUL, B., DOOSHIMA, A.J., IORLIAM B. (2016) Nutritional Composition, Physical and Sensory Properties of Cookies from Wheat, Acha and Mung Bean Composite Flours. International Journal of Nutrition and Food Sciences. Vol. 5, No. 6, pp. 401-406. https://doi.org/10.11648/j.ijnfs.20160506.15

ESAN, T. O., ADESANWO. A.S., DAUDA, O. A., ARISE, A. K. AND SOTUNDE, A.J..(2017). Chemical composition and sensory qualities of wheatsorghum date cookies. Croatian Journal of Food Technology, Biotechnology and Nutrition 12 (1-2), 71-76.
EZEAMA, C. F. (2007). Food microbiology: Fundamentals and Applications Natural Prints Ltd. Lagos. Pp 66-125.

FALADE K., AKINGBALA J. (2010): Utilization of Cassava for Food, Food Reviews International, 27:1, 51-83.

FALOLA, A., ANIMASHAUN, J.O. AND OLORUNFEMI, O.D., Determinants of commercial production of rice in rice producing areas ofKwara State, Nigeria. Albanian Journal of Agricultural Sciences. 13(2):59 - 65, 2014.

GBADAMOSI, S., ABIOSE, S. AND ALUKO, R. (2012), Amino acid profile, protein digestibility, thermal and functional properties of Conophor nut (Tetracarpidium conophorum) defatted flour, protein concentrate and isolates. $\begin{array}{llll}\text { International Journal of Food } & \text { Science47, }\end{array}$ https://doi.org/10.1111/j.1365-2621.2011.02901.x

GIBSON, R.S KING., J.C. and LOWE N. (2016). A Review of Dietary Zinc Recommendatios Proceeding Nutrition Society. 65: 51-60 https://doi.org/10.1177/0379572116652252

HAINIDA, E., AMIN, I., NORMAH, H., MOHD-ESA, N. AND AINUL, Z.A. (2008). Effects of defatted dried roselle (Hibiscus sabdariffa L.) seeds powder on lipid profiles of hypercholesterolemia rats. Journal of the Science of Food and Agriculture, 88: 1043-1050. https://doi.org/10.1002/JSFA.3186

HASMADI, M., SITI FARIDAH, A., SALWA, I., MATANJUN, P., ABDUL HAMID, M. AND RAMELI, A. S. (2014). The effect of seaweed composite flour on the textural properties of dough and bread. Journal of Applied Phycology 26:1057-1062. https://doi.org/10.107/s10811-013-0082-8

HENRY, P., EDWARD, M. J., ESSIEN, N. A. AND IKPEME, C. E., (2016). Nutritional Evaluation of Breadfruit and Beniseed Composite Flours. American Journal of Food Science and Technology, Vol. 4, No. 6, 182-187 https://doi.org/10.1269/ajfst-4-4-5

HOODA, S. AND JOOD, S. (2005). Organoleptic and nutritional evaluation of wheat biscuits supplemented with untreated and treated fenugreek flour. Food Chemistry 90: 427-435. https://doi.org/10.116/j.foodchem.2004.05.006

HOTZ, C., AND BROWN, K.H. (2004). Assessments of the Risk of Zinc Deficiency in Populations and options of its Control Food Nutrition. Bull. 25: 94-204. https://doi.org/10.4067/SO717-75182010000200014

IWE, M.O. (2010). Handbook of Sensory Methods and Analysis. Projoint Communication Services Ltd., Enugu.75-78 p.

IWE, M.O., OKEREKE, G.O., AGIRIGA, A.N. (2014). Production and Evaluation of Bread Made from Modified Cassava Starch and Wheat Flour Blends. Agrotechnol 4: 133. https://doi.org/10.4172/2168-9881.1000133

JOY, E.J.M., ANDER, E.L., YOUNG, S.D., BLACK, C.R., WATTS, M.J., CHILIMBA, A.D.C., CHILIMA B, SIYAME, E.W.P., KALI MBIRA, A.A., HURST, R., FAIRWEATHER-TAIT, S.J., STEIN, A.J., GIBSON, R.S., WHITE, P.J. AND BROADLEY, M.R. (2014).Dietary mineral supplies in Africa. Physio Plantarum https://doi.org/10.1111/ppl.12144.

LEE, K. AND BRENNAND C.P. (2005) Physiochemical, textural and sensory properties of a fried cookie system containing soy protein isolate. International Journal of Food Science and Technology, 40(5), 501-508 https://doi.org/10.1111/j.1365-2621.2004.00948.x

MASHAYEKH, M., MAHMOODI, M.R., AND ENTERAZZI, M.H. (2008) Effect of fortification of defatted soy flour on sensory and rheological properties of wheat bread. Int. J. Food Sci. Technol., 43: 1693-1698. https://doi.org/10.1111/j.1365-2621.2008.01755.x

MEPBA, H. D., EBOH, L., AND BANIGO, D.E.B. (2007). Effect of processing on the nutritive composition and consumer acceptance of some Nigerian edible leafy vegetables. African Journal of Food, Agriculture, Nutrition and Development. 7 (1): pp 1-18

MOHSEN, S.M., FADEL, H.H.M., BEKHIT, M.A., EDRIS, M. AND AHMED, Y.S. (2009) Effect of substitution of soy protein isolate on aroma volatiles, chemical composition and sensory quality of wheat cookies, International Journal of Food Science and Technology 44(9) 1705-1712 https://doi.org/10.1111/j.13652621.2009.01978.x

NDIFE, J., KIDA, F. AND FAGBEMI, S. (2014). Production and quality assessment of enriched cookies from whole wheat and full fat Soya. European Journal of Food Science and Technology 2(1), $19-28$

NDULAKA, J. C. AND OBASI, N. E. (2018). Effects of Storage on the Proximate And Beta-Carotene Contents of Cookie-Like Products Formulated From Blends of Wheat Flour And Garri From Biofortified Cassava Varieties. 
IOSR Journal of Environmental Science, Toxicology and Food Technology, Vol. 12 (6): 2319-2399. https://doi.org/10.9790/2402-12060189100

NILUFER, D., BOYACIOGLU, D. AND VODOVOTZ, Y. (2008). Functionality of soymilk powder and its components in fresh soy bread. Journal of Food Science, 73: 275-281. https://doi.org/10.1111/j.1750-3841.2008.00727.x

NIBA, L. L., BOKANGA, M. M., JACKSON, F. L., SCHLIMME, D. S., AND LI, B. W. (2002). Physicochemical properties and starch granular characteristics of flour from various manihot esculenta (cassava) genotypes. Journal of Food Science, 67(5), 1701-1705. https://doi:10.1111/j.1365-2621. 2002.tb08709.x

NOOR AZIAH, A. A. AND KOMATHI, C. A. 2009. Acceptability attributes of crackers made from different types of composite flour. International Food Research Journal 16: 479-482 https:www.scridb.com/doc/315486861

NWAKALOR, CHIZOBA N. (2014). Sensory Evaluation of Cookies Produced from Different Blends of Wheat and moringa Oleifera Leaf Flour. International Journal of Nutrition and Food Sciences. Vol. 3, No. 4, pp. 307-310. https://doi:10.11648/j.ijnfs.20140304.21

OBIEGBUNA, J. E., AND BABA, S. S. (2001). Proximate composition and sensory properties of peanut and melon seed butter blends. Journal of Sustainable Agriculture and the Environment, 3(2), 326 -330.

OLAPADE, A. A. AND ADEYEMO, A. M., 2014. Evaluation of cookies produced from blends of wheat, cassava and cowpea. International Journal of Food Studies, Vol. 3, 175-185. https://doi:10.7455/ijfs/3.2.2014.a4

OLATUNDE, S. J., OYEYINKA, A. O., ADETOLA, O. A., OYEYINKA, T. O. OWOLABI, T.O. (2016). Physicochemical properties of pro-vitamin a cassavawheat Composite flour biscuit. Food in Health and Disease, scientificprofessional journal of nutrition and dietetics, 5 (1) 20-26

OLUWAMUKOMI, M., OLUWALANA, I., AKINBOWALE, O. (2011): Physicochemical and sensory properties of wheat-cassava composite biscuit enriched with soy flour. Afri. J. Food Sci. 5 (2), 50-56.

OLUYEMI, E. A., AKILUA, A. A., ADENUYA, A. A. AND ADEBAYO, M. B. (2008). Mineral contents of some commonly consumed Nigerian foods. Journal of Science, 11: 153 - 157.

ONIMAWO, I. A., NMEROLE, E. C., IDOKO, P.I. AND AKUBOR, P.I (2003). Effects of fermentation on nutrients and some functional properties of pumpkin seed (Telfariaoccidentalis). Plant food Hum Nutr (Impress). (2) 3-8 https://doi:10.1023/b:qual.0000040330.58205.dc

ONWUKA, G.L. (2005). Food Analysis and Instrumentation. Theory and Practice. Lagos, Nigeria pp122-128: Naphthal print, Surulere.

OYEYINKA, S.A., OYEYINKA, A.T., KARIM, O.R., TOYEEB, K.A. AND OLATUNDE, S.J. (2014) Biscuit making a potentials of flours from wheat and plantain at different stages of ripeness. Croat J Food Sci Technol 6: 36-42. https:www.academic.edu/10925264

OYEYINKA, S. A., SINGH, S., VENTER, S. L. AND AMONSOU, E. O. (2016b). Effect of lipid types on complexation and some physicochemical properties of bambara groundnut starch. Starch-Stärke, https://doi 10.1002/star.201600158.

PUTSEYS, J., LAMBERTS, L., DELCOUR, J. (2010): Amylose inclusion complexes: Formation, identity and physico-chemical properties. J. Cereal Sci. 51 (3),238-247. https://doi:10.1016/j.jcs.2010.01.011

RODRIGUEZ-AMAYA, D.B., KIMURA, M., (2004). HarvestPlus Handbook for Carotenoid Analysis. HarvestPlus Technical monograph series 2, HarvestPlus c/o International Food Policy Research Institute, Washington, DC, pp. 1-58.

ROSELlE, C.M., SANTOS, E. AND COLLAR, C. (2009).Physiochemical properties of commercial fibres from different sources: a comparative approach Food res int.42:176-184 https://doi: 10.1016/j.foodres.2008.10.003.

SANNI, T.A., ALABI, O.O. AND OGUNDELE, J., (2016). Physicochemica Properties and Fatty Acid Profile of Gamma-irradiated Sorrel Seed (Hibiscus sabdariffa) Flour and Oil. Applied Tropical Agriculture Volume 21, No. 3, 151 157

SATYANARAYANA, U. AND CHAKRAPANI U. (2013). Vitamins, Mineral Metabolism. Biochemistry. Haryana, India. Elsevier India Pvt. Ltd. pp:116-159, 403-409.

SENGEV, I. A., GERNAH, D., BUNDE-TSEGBA, M. (2016): Physical, chemical and sensory properties of cookies produced from sweet potato and mango mesocarp flours. Afri. J. Food, Agric. Nutri. Dev. 15 (5), 10428-10442.

SLAVIN, J.L. (2005). Dietary fiber and body weight. Nutr., 21: 411-418. https://doi: 10.1016/j.nut.2004.08.018

SNEDECOR, G.W. AND COCHRAM W.G. (1976) Statistical Methods, 6th ed., pp.258-299, The Iowa State University Press, Ames IA, USA.

TOUNKARA, F., AMADOU, I., LE, G.W. AND SHI, Y.H. (2011). Effect of boiling on the physicochemical properties of Roselle seeds (Hibiscus sabdariffa L.) cultivated in Mali. African Journal of Biotechnology. 10, 18160-18166. https:www.ajol.info/index.98567

UBBOR, S.C. AND AKOBUNDU, E.N.T. (2009). Quality Characteristics of Cookies from Composite Flours of Watermelon Seed, Cassava and Wheat $\begin{array}{lllll}\text { Pakistan Journal of Nutrition } 8 & \text { (7): } & 1097-1102\end{array}$ https://doi:10.3923/pin.2009.1097.1102

UDENSI, A.AND EKE, O. (2000). Proximate composition and functional properties of flour produced from Mucuna cochinensis and Mucuna utles
In Proceedings of the 1st Annual Conference of the College of Agriculture and Veterinary Medicine Abia State University. 10-13th Sept. 2000.Pp 170-174. WARDLAW, G.M. (2004). Perspectives in Nutrition. (6th ed.).McGramHill Companies, New York, U.S.A. https://trove.nla.gov.au/version/27211812 